International Journal of Social Learning

December 2021, Vol. 2 (1), 55-68

e-ISSN 2774-4426 and p-ISSN 2774-8359

DOI: https://doi.org/10.47134/ijsl.v2i1.68

\title{
Globalization, Academic Migrants and Education: Case Study of Palestine Scholars in India
}

\author{
Tanjeel Ahmed ${ }^{1 *}$ \\ ${ }^{1}$ Aligarh Muslim University, India \\ *e-mail: tanjeelahmad88@gmail.com
}

\begin{abstract}
The Israel-Palestine conflict is one of the most complex issues in nature; the issues of sovereignty, territorial issues, and much more are still unresolved in the Israeli-Palestine conflict. More specifically, this ongoing conflict had affected the Palestinians' life, identity, psychology, and development. A thorough literature review reveals that there is an absence of scholarly research in the area of academic migration of Palestinian scholars about the educational challenges in Indian universities. This research uses a qualitative approach with case study methods. The researcher used field study and Snowball Sampling methods to select the study samples. The indepth perception of six cases was analyzed on the issues of their stay in India, educational challenges in universities, a pedagogical transaction in the classroom, and the different cultural contexts (of their home country and destination country). The study revealed the academic disparities they face about language were problematic, and this hampered the conversation. Critically understanding the international scenario and position of the Palestinian scholars, this research study will contribute to the development of an empathetic understanding of the students from different conflict zones.
\end{abstract}

Keywords:

Academic Migrants; Globalization; Education; Brain Drain Concept.

\begin{abstract}
ABSTRAK
Berbicara tentang konflik Israel-Palestina, itu adalah salah satu masalah yang paling kompleks di alam; masalah kedaulatan, masalah teritorial, dan masih banyak lagi yang belum terselesaikan dalam konflik Israel-Palestina. Lebih khusus lagi, konflik yang sedang berlangsung ini telah mempengaruhi kehidupan, identitas, psikologi, dan perkembangan orang Palestina. Sebuah tinjauan literatur menyeluruh mengungkapkan bahwa ada kelangkaan penelitian ilmiah di bidang migrasi akademik sarjana Palestina dalam kaitannya dengan tantangan pendidikan di universitas-universitas India.
\end{abstract}


Penelitian ini menggunakan pendekatan kualitatif dengan metode studi kasus. Peneliti menggunakan metode studi lapangan dan Snowball Sampling untuk memilih sampel penelitian. Persepsi mendalam dari enam kasus dianalisis tentang masalah mereka tinggal di India, tantangan pendidikan di universitas, transaksi pedagogis di kelas, dan konteks budaya yang berbeda (negara asal dan negara tujuan). Studi ini mengungkapkan perbedaan akademis yang mereka hadapi dalam kaitannya dengan bahasa benar-benar bermasalah, dan ini menghambat percakapan. Memahami secara kritis skenario internasional dan posisi para cendekiawan Palestina, studi penelitian ini akan berkontribusi pada pengembangan pemahaman empatik para siswa dari zona konflik yang berbeda.

\section{Kata Kunci:}

Migran Akademik, Globalisasi, Pendidikan, Konsep Brain Drain.

\section{Introduction}

India being a secular republic, always supports the freedom and democracy of its people and also promotes it in the world platform. India's international relations, treaties with different countries, and its take on any problems through the peace talks are well known all over the world. The solidarity of India' with Palestinians from the time of Mahatma Gandhi through the voice of freedom struggle. India has good relation with Palestine because of its empathy. India voted against the partition of Palestine at the United Nations General Assembly. India was the sole non-Arab country that recognized PLO in1974, and it was the merely country that recognized the state of Palestine in 1988 (ROIRAMALLAH). The visit of Prime Minister Modi in Israel in 2017 and the ban on Qatar in the Arab world about Palestine had raised different debates in international politics. I.R. (International relation) experts in India and the world present their views on the situations, but actual sufferers are the native residents of Palestine. Palestine and Israel conflict had almost completed more than six decades yet remained unsolved. The people in Palestine are suffering war in the areas of Gaza and Occupied Territory. "It also illustrates the crucial importance of a careful reading of recent Palestinian history to attain an understanding of the Middle East conflict" (Khalidi, 2007).

In short, the conflict had turned into havoc in the life of the people of Palestine. "Such a topic provokes a sequence of questions that relate to the present as much as to the past: What purpose is served by such a study when, nearly six decades after 1948, an independent Palestinian state - in any real sense of the word "independent"-still does not exist, and when its establishment continues to face formidable obstacles? (Khalidi, 2007) More specifically, this ongoing conflict had affected the life, identity, psychology, and development of the people living there. Even it is observed that Palestinians who are living in the West Bank and Gaza (which came under the Israeli occupation after 1967) and the villages had many incidences in relation to the settlements, citizenship, life, and freedom. Christopher J. Lee quoted Noam Chomsky while he interviewed him; Chomsky said on 
the issues of the construction of the Separation Wall (a huge wall is built by Israel for security reasons); he said "a large part of it is taking control of the water supplies. The main aquifer is mostly under the West Bank. A lot of the settlement programs since 1967 have been designed with long-term hydrological concerns in mind to make sure that Israel controls the aquifer. Actually, Israel uses almost eighty percent of it or so anyway. Even the settlers have green lawns and swimming pools, while the Palestinian villages next door may not have water at all. They may have to go miles to get a bucket of water. The separation wall will help cement control over the water sources and take some of the most arable Palestinian lands, and it will ultimately dispossess a couple hundred thousand Palestinians, who are probably not going to be able to survive there." (Lee, 2004).

With the different political conditions and upheaval, the majority of the children and youth are suffering in their education. With globalization and with the expansion of the areas of work, industries, and trade between the different nations, there is also a change in the movement of the people. In this regard of movement in relation to the educational purposes among the scholars to gain a higher level of educational knowledge led to the movement in scholar communities. Now day's scholars move from one campus to another in large numbers. Similarly, the youth from Palestine are moving to other countries for education. As researchers locate the reasons of migration according to Siddle (2000) that "moving to a new space to acquire HE can be considered as migration for social mobility, motivated by 'pull' factors of the target host location and 'push' factors from the region of origin." (Cited in Arar, Masry-Harzalla \& Haj-Yehia, 2013, p.53). If researcher analyzes the "pull" and "push" factors, they are the major reasons behind the migration. Push factors may include the areas (the geographical landscape), culture; country's economy, etc., the migration for the educational purposes may be temporary but heavily affects the person in transition. For a long period, the movement had been observed but not exhaustively studied in relation to this mobility. When in recent times, academic mobility crossed the international borders, leading the research scholars to unravel the phenomenon and put it in the scholarly table for understanding the transition and movement in relation to academics.

Academic migration, in a broader sense, had been associated with globalization and, to be more precise, the 'brain drain concept.' Therefore this area significantly requires critical attention in relation to the economic, social, and educational trends. Now the present study focuses on the Academic migrants from Palestine since they are migrating to gain academic expertise. Still, the most common thing they share is the 'violence they faced in their homeland,' and this violence hammered the possibilities of their livelihood and development in their native place. (Education and chronic crisis in Palestine).

A thorough review of the literature revealed a severe shortage of scholarly literature, which can point out the experiences related to the academics by the migrants who come from the international conflict zone. Also, there is a lack of insights into diverse educational, cultural, and societal settings, which can affect the discipline, knowledge, inter as well as intrapersonal 
relationship in relation to the students who migrate for studies known as "Academic Migrants" (Bönisch-Brednich, 2011). Here in this research study, we had considered the Academic migrants as the sample of the study. With no wonder, the "Academic Migrants" (Bönisch-Brednich, 2011) term is taken up in this research study. Academic migrants are "academic who has experienced a cultural transition involving different cognitive styles of learning and who locates their field of inquiry in a supranational frame of reference" (Bönisch-Brednich, 2011). "The fact that migration is always unsettling and hardly ever easy tends to be underestimated by academic migrants and their new universities alike. Academic migration is often based on the assumption that moving campuses and departments is happening in a safe realm of disciplinary attachment and a universal academic culture that works on a pan-university level" (Bönisch-Brednich, 2010, p. 172). The research aims to explore the challenges the students face in Indian academic institutions and what are their lived experiences. The present research revolves around the objective: To study the educational challenges faced by the Academic Migrants (AM) in Indian Universities.

\subsection{Palestine And Palestinian}

Palestine is the area of the eastern Mediterranean region situated in the Western part of Asia included Israel. Palestine is divided into several territories, the Gaza Strip (along the coast of the Mediterranean Sea) and West Banks (the area of the West Jordan River). The term Palestine has been controversially many times with this small region (Farsoun \& Zacharia, 1997). The small region of this land claims the Holy Land by the three great religions of the world. Islam in Palestine occupies a special place in the Muslim imagination and faith. Jerusalem is the third most holy place in Islam. In the Islam religion, there is the importance of direction to offer Namaz. Jerusalem is known for providing the direction of Qibla for the Salah (prayer). So, Palestinians are people of three different religious faiths. They are Muslims, Jewish and Christian faith. In the $20^{\text {th }}$ Century, it was seen that the claim by the Jewish and the Arab National Movement and the conflict has led to long violence between both communities and sometimes open warfare. For a long period of time, Palestine was under Islamic rule, but after the end of World War I, it was under the Ottomans. When there was a collapse of the Ottoman Empire, Palestine went under British mandate (Farsoun \& Zacharia, 1997). In 1922, the boundaries of the mandate Palestine included an area of 27,000 sq. km on which 660,641 Muslims and Christian Palestinians live together with 80,000 Jews. The British mandate period witnessed a large number of immigration of Jews from all over the world. The Jews who came from other places have welcomed by the Jewish Agency and the World Zionist Organization (Matthews, E. 2011). They welcome all the Jews with the support of the British government. The purpose of supporting the Jews was to increase the numbers of Jews in the state and wanted to establish the Jewish homeland. The Israeli-Palestinian is a world-historical conflict that still does not resolve, and it is part of the wider Arab-Israeli conflict. At present, the vast majority of Israelis and Palestinians agree a two-state solution is the best way to end the conflict. The roots of the conflict can be traced to the late 19th Century, which saw a rise in national movements, Including Zionism and Arab nationalism. Zionism, the Jewish national movement, was established as a Political movement in 1897. Following World War I and the dissolution of the Ottoman Empire, Palestine came under the control of the United Kingdom through the Sykes-Picot 
Agreement. The League of Nations approved, and more Jews entered Palestine. In May 1945, after the German surrender, the Jewish Agency wrote Prime Minister Churchill demanding the full and immediate implementation of the Biltmore resolution, the cancellation of the White Paper, the establishment of Palestine as a Jewish state. In 1947, the U.N. approved the partition of the British Mandate of Palestine into two states: one Jewish and one Arab. The Jewish leadership accepted the plan, but Palestinian Arab leaders rejected the plan. The three largest Abrahamic religionsJudaism, Christianity, and Islam-claim Jerusalem in their Religious and historical narratives. There are about four million Palestinians and their descendants who were expelled or fled from Israel Following its creation citing the Universal Declaration of Human Rights and U.N. General Assembly Resolution 194, adopted in 1948, which says: "the refugees wishing to return to their homes and live at peace with their neighbors should be permitted to do so at the earliest practicable date."(U.N., Resolution 194(III)). So, the Palestinians encountered a whole series of unrest, war, insurgency, and conflict for many years. This had hammered the proper development of the country, and the political upheavals had led people to become refugees in their own homeland. Some people, as well as students, migrate for a living, and some migrate for higher education as the children suffer in school and universities due to the war and conflict every now and then. (The officials' site of United Nations, the Palestine Question)

\subsection{Rationale Behind The Palestinian Academic Migrants}

Research related to investigating the phenomenon of academic migration from the areas of the conflict zone is rarely done in the past. Moreover, the lack of research, especially in teachinglearning areas, makes this an essential step towards exploring the unexplored. As it has been previously documented that the research samples are students who were residentially situated in the conflict zone of Palestine; therefore, this research will certainly help in understanding the positioning of the Indian academia to cater to a new challenge in the areas of education, migration studies and International relations and its impact on the society. Globalization has made the world a global village, and all the residents of the village in one form or the other affect life in the society. In the ever fast-changing academia, it is the role of the institutes and the educators to provide a safe space for the migrants who enroll in the universities for higher education in India. Developing a proper understanding of the challenges the scholars face due to their migration into a new culture forces them to either adapt or return back to their native place or struggle all the ways. To reiterate, the present research revolves around the objective: To study the educational challenges faced by the Academic Migrants (AM) in Indian Universities.

\section{Methods}

The present research finds its roots in the qualitative approach. The study employed rigorous qualitative interviews with the samples to illuminate the challenges they faced as being Palestinian Academic Migrants who study in Indian universities. As a researcher, I assume that the experiences of the challenges of the migrants, their methods to cope with the situations, their description of the 
coping had definitely influenced and shaped their identities as well (Neisser, 1994). The lived experiences that the migrants revealed painted their perceptions of the experiences they faced and how they gave social and cultural meaning to them (Chase, 2000). We have tried to look at the possible cause and effects that emerged in given academia within the country. Also, we have tried to ponder on how social phenomena, religious beliefs, and interactions are related to the whole scenario in the Indian context (Qyen, 1990, p.6). The researcher has tried to understand how migration is different in relation to gender and how they relate to it as a whole. We wanted to understand how migration to different and for the new, cultural, and national spaces with their special characteristics affected them.

\subsection{Participants And Procedure}

The field of the study and sampling method in this research had been a complex one. To reiterate, the academic migrants from Palestinians are spread all over India. They are highly scattered and pursue higher education in different universities of India. This step is two phases' steps, also, to submit that the samples were chosen in the first step through the 'gate keepers' (community members in the position of official authority). Then in the second phase, the researchers used Snowball Sampling methods to select the samples of the study. The researcher approached Palestinian Academic Migrants in different parts of India for the interviews. Here my aim was to use a mixture of the methods, that is to look at academic migrant narratives, the stories which the scholars use to make sense of their experience; and to look at the cultural difference in living, personal interactions, classroom interactions, bureaucratic procedures and possible responses to foreign staff by local academics, (for example gossip, accounts of actual meetings and conflicts or supportive and helpful actions). We can submit that contributors to this research work, approached by the researchers, comprise six academic scholars selected on the basis of the following criteria:

1. Palestinian Origin

2. Migrated for Studies ( not refugees in India)

3. Academic Scholar in Higher Educational Institutions

4. Current residency in India.

It was taken into consideration that proper representation from higher education should take place. Therefore the study involved the educational course from lower (Graduation) to a higher degree (Doctoral Scholars) to ensure the problems and challenges at each step in Indian academia. In-depth interviews were conducted with the Palestinian Academic Migrants to obtain rich and authentic first-hand narratives concerning their experiences in Indian academia. All the interviews were conducted in English. The objective of the study was mentioned, and their consent was taken. In order to maintain the confidentiality of the Palestinian AM, the identity of the university, name, and places of interviews are held confidential. 
Table 1. Respondents' Personal Profile

\begin{tabular}{lllllll}
\hline $\begin{array}{c}\text { Case } \\
\text { (Age) }\end{array}$ & Sex & Qualification & $\begin{array}{c}\text { Course in } \\
\text { India }\end{array}$ & $\begin{array}{c}\text { Community type } \\
\text { in Palestine }\end{array}$ & $\begin{array}{c}\text { Stay in } \\
\text { Palestine }\end{array}$ & $\begin{array}{c}\text { Stay in } \\
\text { India }\end{array}$ \\
\hline $\mathrm{A}(40+)$ & M & M.Phil. & Ph.D. & Urban & $20+$ & $5+$ \\
$\mathrm{B}(40+)$ & M & M.Phil. & Ph.D. & Urban & $20+$ & $5+$ \\
C(30+) & M & Grad. & Post Grad. & Rural & $20+$ & $2+$ \\
D(25+) & M & Grad. & Post Grad. & Urban & $20+$ & $1+$ \\
E(20+) & M & Under Grad. & Post Grad. & Rural & $20+$ & $2+$ \\
F(30+) & F & Post Grad. & Ph.D. & Refugee Camp & $20+$ & $2+$ \\
\hline
\end{tabular}

The descriptions of the student provide a glimpse of their educational qualification, the course being studied in India, and their presence and interaction with the Indian culture and people. It was also confirmed from the birth itself they spent a considerable portion in their native place (Palestine).

\subsection{Data Analysis}

The interviews were conducted with the Palestinian AM were open-ended. The interviews underwent coding and decoding from which the constructions of categories were done, and then that resulted in the emergence of themes. The findings were organized, and thematic classification was done. To fortify reliability, the analysis was conducted and acted as a critic, reinforcing the analytical structure at the different stages of analysis (Marshall \& Rosman, 1995). Since this was a small sample from a specific group of students, this limits the generalization of the findings to other social arenas.

\section{Results And Discussions}

\subsection{Reasons For Migration}

The cases migrated to India for their dream of higher education. The reasons were varied, such as obtaining a higher degree, improving the English language, and improving education in Palestine (after returning back to Palestine). In relation to the migration of Case $\mathrm{B}$, he told:

"Free-space which not available in Palestine because of occupation regulations; we have no Ph.D. programs in Palestine, no fear of arresting by Israel which stops my study."

Case A and Case B are involved with their Job in India, whereas others are only mere students 
wholly devoted to educational developments. Case A and Case B both are higher officials, but they both are keen to improve their educational qualifications. Thus, Case A got special permission from the Indian government to pursue his education in an Indian university. He said:

I asked why can't I study being working in the (the name is not being mentioned due to ethical reasons) working here. I am doing no wrong. I request you to please pay consideration to my plea and allow me to study.

Case F (Doctoral Research Scholar) told:

“I came for studies. I don't know the country, but the education brought me here".

Case C (Grad.) also had a different view in relation to the studies in India. He said:

"I wanted to do my Post Graduation in mathematics. Also, I don't know English well.

In India, the education is good, and expenses are less."

The overall discussion points to the problems of conflict, which hindered the development of the scholars. According to Giroux (2006), "any discourse about the future has to begin with the issue of youth because young people embody the projected dreams, desires, and commitment of a society's obligations to the future" (p.230). Despite the different atrocities, the youth in Palestine are migrating for better education and development in other countries. The narrative is too pointed and is in support of Giroux.

\subsection{Educational Challenges in the Universities}

\subsubsection{Academic Dealing}

Case A and Case B were elderly were of the views as same as the students in relation to the grads (Case $\mathrm{C}$ and Case E). The cases were of the view that the main problem they faced in the application process and the documentation in the universities. Also, they have to move from one department to the other without any proper knowledge. The academic staffs were helpful for all the students, but the major barrier was 'language.' The scholars were not well acquainted with the Hindi language were as the academic staff was unable to fully articulate in English. It is not with the behavior but the language problem which hammered the application process a great deal.

\subsubsection{Admission Process}

Striking new challenges the AM faced in Indian universities was in relation to the admission process. Case E (Under Grad. Student) said that.

"I came due to the subject. I especially wanted to join the course of civil engineering, but due to the lapse of time, I had to decide fast. So, there was only one seat in 
Industrial chemistry was left. I just applied for this course since I had no facility available in my own country where such subject is being taught."

According to case $\mathrm{C}$, "My admission was done by my senior. He was from the Physics department. He called me in Palestine and informed me about the courses of M.Sc. (Mathematics). He did all my formalities, and then I got admission. Due to this process taking a lot of time, I arrived late and missed most of the classes. Nobody gave me notes and didn't explain anything. The midterm was within ten days."

This problem was serious as the students from other countries are rarely accepted and cherished by the local students. This goes in accordance with the research results of BönischBrednich (2014), where she already pointed on the "Investigation into the field of academic migration requires us not only to look at the research, teaching, and administration but also at the fields of engaged contact with local people such as students, academic colleagues, and administrators." (Bönisch-Brednich, 2014). As a researcher, I would like to submit that if I am working on the global transfer and trading of knowledge as well as the challenges in the education that also higher education, it is the central focus of our research, looking at the interaction between teaching staff, educators and students forms a vital part of our research study. Teaching-learning processes are not only one of the various realms that can change when moving not just campuses but also countries.

\subsubsection{Pedagogical Problems}

The teaching-learning process is a significant part of the scholar's life and is often an arena in which the conflict of cultures plays out aloud and openly, affecting the affective domain of the migrants. That can be painful, that can be helpful, or it can give new heights to adjustment too. Also, it can accelerate the settling and unsettling of foreign academics. This is also an area that lends itself to the forming of key narratives by academic migrants, and many stories which are deeply reflective, some resentful in tone, and some joyous, are centered on the migration experience in the classroom.

\subsubsection{Language Problem}

In relation to the pedagogical teaching-learning process, the problem came during teacherstudent interaction in the class. Especially Case $\mathrm{C}$ had a lot of problems in the classroom transaction in the class. He said:

I cannot understand what the teacher taught in the class, as he mostly conversed in Hindi. I understand that many students in India do not know English fully, but as I am not an Indian, I can't make out what is happening in the class. When the teacher told me what I understood, I always kept quiet. Once, it happened that the teacher asked to answer the question, and I was like what was asked, 'I don't know." 
Case $\mathrm{F}$ had faced a problem related to the language in the classroom. She was being ignored in the class as teachers mostly conversed with whom she felt comfortable.

Case A, Case B, and Case D had no such severe interaction with the challenging pedagogical classroom as the teaching-learning were on to one interaction, not fully classroom style. But Case B pointed to the accent of English as problematic. Case D was TOFEL qualified, so they didn't encounter many such difficulties.

Teacher Student Classroom Interactions were more for the course, which required daily attendance and regular classroom teachings. Case $\mathrm{C}$ had felt the situation in the classroom since his first class in the university. This goes in accordance with the study of Mills and Harris (2004). They also proposed that the migrants do face unexcited behaviors in the classrooms. "The unexpected differences, however, are often most acutely felt when the migrant encounters his or her first class of local students." As Mills and Harris have pointed out, "teaching is not just a dialogical relationship between pedagogue and pupil. It is a social process occurring within institutions, each with their own unique histories and pedagogic cultures" $(2004, p .3)$.

The findings put the lived experiences of the Academic Migrants forwards in Indian academia and their coping strategies in different countries with different cultures, pedagogical transitions, and much more. They have seen transitions between two different worlds, ideologies, and even cultural differences.

The researcher met with six migrants from Palestine who are studying in India. Among them, there are three postgraduate students and three are Ph.D. students. Few were there from the refugees camps, rural areas, and urban areas from Palestine. When they get admissions in the Indian universities, and during the sessions, all have the same challenges but also benefit from learning in their universities. It's natural when the person enters a new culture and new place, the person definitely would face the challenges of languages, culture, dressed, festive, and the most challenging for them is food. They articulate that while they are passing through the street, the people remark on them about their ethnic identities and languages at shops.

On the other hand, they were happy and appreciated the Indian education system; sometimes, the challenges are not merely for the foreigners but also for Indian students in the academic institutions. Migrants were happy the receive scholarships from the Indian government. There are several government bodies that provide scholarships for international students in different fields. They appreciated the Teachers and colleagues of the universities, and they said, 'most of the teachers are helpful, they help us because we are foreigners, even the classmates also have helped them a lot.

So, the research questions match the research findings. The sources helped in finding the research questions. Some more questions can be clear from the followings questions with academic migrants. 


\subsection{Examination, University Hostel, Scholarships, and Academic Migrants}

Case D said that "Actually, the educational transaction here in India depending on blocks for each semester that must be finished to shift to the next semester, not like Palestine, each course have a number of hours for studying per week and the student have the ability to choose his subjects. Even the way of calculating GPA is different, and I don't know how they are calculating; in Palestine, there is a formula for calculating GPA, at least it giving you a percentage." The examination system and results are different for different countries. There is a need for proper information in this regard.

According to Case, D on hostel was "hostel facilities, what is written is different from reality, college is not providing the facilities as they promise." Whereas Case F said: "I had a very horrible experience in the hostel. When I came back from my home (Palestine), the students snatched my belonging and ate my stuff. My mother prepared it for me. I was very sad and annoyed in such circumstances. Then I left the hostel". Case C and Case E, from the beginning, only stayed outside the campus. They were of the view that since our food habits are different, we decided to be outside the campus.

Case D said, "I have applied to leave the hostel after staying one year, but our request is rejected for no reason." The experiences were really different in relation to the AM since they are from the conflict zone. Case F was ferocious about the fact that Indian does not understand what is living in the conflict areas with bombings and living for life. As the AM were admitted to the university had gone through the phases of 'Cultural Shock' as well as "cultural anxiety." This is in support of the findings of Bönisch-Brednich, 2014, p.20) "having gone through periods of incomprehension, of frustrations, of feeling alienated, of wading through a fog of mysterious misunderstandings and feelings of cultural anxiety."

In relation to the scholarship, many cases are either unaware or complain about its structure. According to Case F and Case D, the money is less as compared to the expenses. Case D is from the Gaza Refugee camps, where she is short of monetary funds and lacks income sources in India.

\subsection{Interactions in the Indian Context}

Indian culture was new to the Palestinian AM. The culture of India gave a soothing feeling of belongingness to some scholars but developed hate feelings in some others. The secular republic had many people with different cultural faiths that could be endorsed by the words quoted by the cases. Case C said that “I don't know about so many faiths in India. I don't know what they speak as the language is different. Their norms are different."

Case E said: "I don't know about Indian girls and Indian names even. I am always confused by their name in the beginning. They did not help at the beginning of the semester. But later on, a Hindu girl saw me suffering in education. One day she came to me and took me to the Xerox shop 
and gave me all the reading material which I wanted. I didn't understand, but I was thankful."

Case F, who lived in an on-campus dorm, explains the difficulties involved in her transition and integration with Indian culture. Case F said that "the people made fun of me in Hindi and they used to snatch away my belongings in the hostel, and this made me sad. The Indian girls told me that you have to adopt the Indian culture when you are in India....you came to India...understand" Differences in the way of talking behavior with the gender in the Indian context, dress code, and gender behavior were astonishing to the Academic migrants since in one or the other way it shaped their living and thinking and affected the activities and learning and behavior in Indian context so if we as a researcher see through her narrative. She (Case F) explores issues relating to the cultural adjustment of academic migrants. So there is a need for a heightened awareness of the reciprocal responsibilities on the shoulders of all members of the academic community" (Mason \& RawlingsSanaei, 2011, p.5). According to Bönisch-Brednich (2010) "fact that migration is always unsettling and hardly ever easy tends to be underestimated by academic migrants and their new universities alike. Academic migration is often based on the assumption that moving campuses and departments is happening in a safe realm of disciplinary attachment and a universal academic culture that works on a pan-university level (p. 172).

\section{Conclusion}

There is a serious need to understand the problem of Academic Migrants, and most important is from which country's theory is coming. The dealing with the teachers and fellow students are needed to understand in the greater context of religion, areas, geography, and psyche of the Academic migrants. In order to eradicate such problems and challenges, it's necessary to orient teacher educators of these new emerging needs in higher education arenas. Also, it is essential for the scholars in India to have an empathetic lookout over the situation rather than behaving in the normal way as they should understand the cultural differences, food taboos, behavioral challenges, and academic anxiety with the academic migrants. There is a need for the proper dissemination of the information of the admission process, scholarships, and academic schedules in relation to the Academic migrants from abroad. Teacher educators should keep in mind that the teaching-learning processes in the classroom should cater to each and every student. The language barrier should be broken with the initiation of the teachers in the classroom.

The residential hostels which were provided were not appropriate. Most of the scholars faced 'cultural shock,' but the point they wanted to convey was that at this stage can be eradicated if collective empathetic efforts are made from the educational institutions in which they were enrolled. The analyses of the cases depicted that they (academic migrants) suffered much from the Indian fellow scholars who made fun of them in the Hindi language, and as they are ignorant, were helpless to respond back. In relation to Palestine (as a native place), religion, and food habits, they faced criticism. This research offers an idea of incorporating an orientation of the academic migrants with the culture of India. 
According to Handal (2014), "in order to traverse through these challenges, it is essential that scholars courageously confront their own culturally-held beliefs about knowledge and education. Above all, these potentially conflicting assumptions about teaching and learning or knowledge itself are to be taken as opportunities for learning, unlearning, and relearning. This process involves learning new perspectives and relearning how we have been approaching some issues. In both cases, we need to re-examine what we know and unlearn concepts to relearn them again from a different cultural perspective. This is a harder and more painful process because, either rationally or irrationally, we build our personal belief system on assumptions that often are based on one-culture stances. Unlearn also implies having the disposition to accept that we must discard some of those beliefs. This is no doubt an uncomfortable process since we have to challenge our belief system, whose mere purpose is, paradoxically, to keep ourselves comfortable. This ongoing cultural and intellectual confrontation, often an unpleasant one, requires openness and courage.

This research paper will definitely add to the international scholarship and provide a shift in Indian academic culture in which academic migrants are accepted as well as respected for their culture, social resources, and intellectual ability, religion as well as their enhanced interpretive ability and their capacity to view the world through multiple lenses.

\section{References}

Bönisch-Brednich, B. (2010). Migrants on campus: Becoming a local foreign academic. In B. Bönisch-Brednich\& C. Trundle (Eds.), Local lives: Migration and the politics of place (pp. 167-182). Aldershot: Ashgate.

Bönisch-Brednich, B. (2014). Cultural Transfer in University Teaching: Academic MigrantPerspectives from Aotearoa/New Zealand. In Mason, C \& Rawlings-Sanaei, F. (Ed.), (pp Academic Migration, Discipline Knowledge and Pedagogical Practice: Voices from the Asia-Pacific. 27-40). Singapore: Springer. https://www.bbc.com/news/world-asia-india-40489746. (Accessed on 1 October 2020).

Chase, S.E. (1994). Narrative inquiry: Multiple lenses, approaches, voices. In N.K. Denzin\& Y.S. Lincoln (Eds.), The Sage handbook of qualitative research (pp. 651-679). Thousand Oaks, CA: Sage.

Farsoun, S. K., \& Zacharia, C. E. (1997). The Palestine and Palestinians. United Kingdom: Westview Press.p.1 Ibid., p.3.

Giroux, H. A. \&Giroux, S.S.(2006). Take back higher education: race, youth, and the crisis of democracy in the post-civil rights era. Palgrave Macmillan.

Handal, B. (2014). Global Scholars as Ambassadors of Knowledge. In Mason, C \& RawlingsSanaei, F.(Ed.), Academic Migration, Discipline Knowledge and Pedagogical Practice: Voices from the Asia-Pacific(pp.27-40). Singapore: Springer.Hadawi, S. (1979). Bitter Harvest Palestine Between 1914-1979. New York: Caravan Books.

Harms, G., \& Ferry, T. M. (2005). The Palestine-Israel Conflict: A Basic Introduction. London: Pluto Press.

https://www.un.org/unispal/document/auto-insert-207882/. (Accessed on 1 October 2020) India- 
Palestine Relations- Ministry of External Affairs.

https://mea.gov.in/Portal/ForeignRelation/Updated_Note_on_India_Palestine_Relations_for_MEA_ Website.pdf. (Accessed on 15 October 2020).

https://www.fmreview.org/education/nicolai-palestine. (Accessed on 30 October 2020).

https://www.un.org/unispal/history2/origins-and-evolution-of-the-palestine-problem/part-i-19171947/\#Origins_and_Evolution_of_the_Palestine_Problem_1917-1947_Part_I. (Accessed on 30 October 2020).

Khalidi, R. (2007). The Iron cage: The story of the Palestinian Struggle for Statehood. USA: Beacon Press.

Khalid Arar, AsmahanMasry-Harzalla \& Kussai Haj-Yehia. (2013). Higher education for Palestinian Muslim female students in Israel and Jordan: migration and identity formation, Cambridge Journal of Education, 43:1, 51-67, DOI: 10.1080/0305764X.2012.749391.

Lee, C.J. (2004). South Africa, Israel-Palestine, and the contours of the contemporary world order, Safundi, 5(1-2), 1-16, DOI: 10.1080/17533170400305123.

Lee, E.S. (1966). A theory of migration. Demography, 3(1), 47-57.

Marshall, C., \& Rossman, G.B. (1999). Designing qualitative research. Thousand Oaks, CA: Sage.

Matthews, E. (2011). The Israel-Palestine Conflict: Parallel Discourses. United Kingdom: Taylor \& Francis.

Mill, D., \& Harris, M. (Eds.). (2004). Teaching rites and wrongs: Universities and the making of anthropologists. Birmingham: The Higher Education Academy Network.

Nations, U. (1990). Origins and Evolution of the Palestine Problem. Retrieved 9 December 2020, from United Nations: https://www.un.org/unispal/history2/origins-and-evolution-of-thepalestine-problem/.

Neisser, U. (1994). Self-narratives: True and false. In U. Neisser\& R. Fivush (Eds.), The remembering self (pp. 1-18). Cambridge, UK: Cambridge University Press.

Quinn, M.A., \&Rubb, S. (2005). The importance of education matching in migration decisions. Demography, 42(1), 153-167.

Qyen, E. (1990). Comparative methodology: Theory and practice in international social research. London: Sage.

Siddle, D. (Ed.). (2000). Migration, mobility, and modernization. Liverpool, UK: Liverpool University Press. 